\title{
Uranium Rhizofiltration by Lactuca sativa, Brassica campestris L., Raphanus sativus L., Oenanthe javanica under Different Hydroponic Conditions
}

\author{
Yikyeong Han ${ }^{1,+}$, Juyeon Lee ${ }^{2,+}\left(\mathbb{D}\right.$, Changmin Kim ${ }^{2}$, Jinyoung Park ${ }^{1} \oplus$, Minhee Lee ${ }^{1}$ and Minjune Yang ${ }^{1, *(\mathbb{C}}$ \\ 1 Department of Earth and Environmental Sciences, Pukyong National University, Busan 48513, Korea; \\ yoogeng@gmail.com (Y.H.); pjy9614@gmail.com (J.P.); heelee@pknu.ac.kr (M.L.) \\ 2 Division of Earth Environmental System Sciences, Pukyong National University, Busan 48513, Korea; \\ juyeon_lee@pukyong.ac.kr (J.L.); changmin_kim@pukyong.ac.kr (C.K.) \\ * Correspondence: minjune@pknu.ac.kr; Tel.: +82-51-629-6634; Fax: +82-51-629-6623 \\ + These authors as co-first author contributed equally to this work.
}

check for

updates

Citation: Han, Y.; Lee, J.; Kim, C.;

Park, J.; Lee, M.; Yang, M. Uranium

Rhizofiltration by Lactuca sativa,

Brassica campestris L., Raphanus sativus L., Oenanthe javanica under Different Hydroponic Conditions. Minerals 2021, 11, 41. https://doi.org/ 10.3390/min11010041

Received: 21 October 2020

Accepted: 29 December 2020

Published: 31 December 2020

Publisher's Note: MDPI stays neutral with regard to jurisdictional clai$\mathrm{ms}$ in published maps and institutional affiliations.

Copyright: (C) 2020 by the authors. Licensee MDPI, Basel, Switzerland. This article is an open access article distributed under the terms and conditions of the Creative Commons Attribution (CC BY) license (https:// creativecommons.org/licenses/by/ $4.0 /)$.

\begin{abstract}
Rhizofiltration experiments were conducted using uranium-contaminated groundwater and lettuce (Lactuca sativa), Chinese cabbage (Brassica campestris L.), radish (Raphanus sativus L.), and buttercup (Oenanthe javanica), which are commonly grown and consumed in South Korea. The results of the rhizofiltration experiments with artificial solutions with different initial uranium concentrations $(18,32,84,116,173$, and $263 \mu \mathrm{g} / \mathrm{L})$ show that the uranium accumulation and bioconcentration factor (BCF) of plant roots increase with increasing uranium concentration in the groundwater. Among the four plants, the uranium concentration in the roots of Raphanus sativus L. is $1215.8 \mu \mathrm{g} / \mathrm{g}$ dry weight, with a maximum BCF value of 2692.7. The BCF value of the artificial solutions with various $\mathrm{pH}$ values ( $\mathrm{pH} 3,5,7$, and 9 ) is the highest under acidic conditions ( $\mathrm{pH} 3$ ) for all four plants. The uranium BCF values based on different hydroponic conditions range from 170.5 to 11580.3 and the results are comparable with those of other studies using similar methods; the highest BCF value was determined for Brassica campestris L. at pH 3. The BCF values of Raphanus sativus L. after the rhizofiltration experiments with genuine groundwater contaminated with uranium are the highest among the four species; that is, 1684.7 and 1700.1 in Oesam-dong and Bugokdong groundwater samples with uranium concentrations of 83 and $173 \mu \mathrm{g} / \mathrm{L}$, respectively. The results of the scanning electron microscope/electron dispersive X-ray spectroscope analyses show that uranium in contaminated groundwater is adsorbed as a solid phase on the root surface. These results demonstrate that Raphanus sativus L. has a high tolerance to high concentrations of uranium and low $\mathrm{pH}$ conditions and a remarkable potential for uranium accumulation.
\end{abstract}

Keywords: bioconcentration; accumulation; radish; phytoremediation; rhizofiltration

\section{Introduction}

Phytoremediation is an economical and eco-friendly remediation method that can simultaneously restore and protect ecosystems [1-4]. Among the phytoremediation techniques, rhizofiltration is a method based on which heavy metals or radionuclides are adsorbed from the groundwater by the roots of plants $[5,6]$. The mechanisms by contaminant accumulation in plant cell are as follows: extracellular precipitation, cell wall precipitation and adsorption, and adsorption within cells by cytoplasmic compartments or vacuoles. Additionally, most cell walls or epidermal layers of plants are negatively charged [7] and can adsorb cations from groundwater for effective remediation [8].

The uranium speciation strongly depends on the $\mathrm{pH}$ of groundwater and is known to be sensitive to the carbon dioxide partial pressure, uranium concentrations, and ligands that form complex compounds $[9,10]$. Generally, the uranyl cation, which is absorbed effectively to the plant cell, is acting actively in under $\mathrm{pH}$. In addition, hydroxide 
complexes were presented in $\mathrm{pH} 6$ and carbonate complexes above $\mathrm{pH} 7.5$ [11]. Among plants used for phytoremediation, sunflowers, legumes, and mustards have been applied to the removal of radionuclides such as cesium, strontium, and uranium [12-15]. The roots of these plants strongly adsorb uranium, which is mainly adsorbed to the surface of the root in combination with the carboxyl group $\left(\mathrm{COO}^{-}\right)$of the cell wall [16,17].

Most studies related to phytoremediation have been conducted on uranium in soil [11,18-22], whereas only a few phytoremediation studies focused on uranium in ground- or surface water. Eapen et al. (2003) [23] performed hydroponic experiments with different initial concentrations (10-5000 $\mu \mathrm{M})$ using hairy root cultures of Brassica juncea and Chenopodium amaranticolor to assess the feasibility for rhizofiltration in uranium-contaminated water. Soudek et al. (2011) [20] also conducted hydroponic experiments with artificially contaminated uranium solutions $(0.1$ and $0.5 \mu \mathrm{M})$ using 20 species of crop plants. To study the accumulation of uranium in artificially contaminated water under various $\mathrm{pH}$ conditions, Helianthus annuus L. [14,24,25], Pisum sativum [11], Hydrilla verticillate [26], Phaseolus vulgaris L. var. vulgaris [27] have been used in the past. These studies suggest that the accumulation of uranium in the roots of plants is the highest when the contaminated water is acidic. With respect to the accumulation of uranium in plants in genuine groundwater and surface water, Lee and Yang (2010) [24] and Yang et al. (2015) [27] demonstrated the uranium removal by rhizofiltration using Helianthus annuus L. and Phaseolus vulgaris L. var. vulgaris in genuine groundwater with high uranium concentrations ( 270 and $240 \mu \mathrm{g} / \mathrm{L}$ ). As mentioned above, various types of plants have been used to investigate the accumulation of uranium in plants, but there is little information on uranium accumulation in commonly consumed crops and vegetables, which are generally grown using groundwater irrigation.

In this study, we investigated the uranium accumulation capacity in lettuce (Lactuca sativa), Chinese cabbage (Brassica campestris L.), radish (Raphanus sativus L.), and buttercup (Oenanthe javanica), which are species that have not been used for uranium accumulation studies in the past and are commonly grown and consumed in South Korea. Rhizofiltration experiments were performed using artificial uranium solutions with different concentrations and $\mathrm{pH}$ values to determine the amount of uranium accumulated in each plant. We also conducted rhizofiltration experiments using genuine groundwater contaminated with uranium. The amount of uranium accumulated in the rhizofiltration experiments was quantified by using the uranium bioconcentration factor (BCF) to verify the relative accumulation capacity of these plants by comparing it with previous research results.

\section{Materials and Methods}

\subsection{Plant Cultivation}

Four species, lettuce (Lactuca sativa L.), Chinese cabbage (Brassica campestris L.), radish sprouts (Raphanus sativus L.), and buttercup (Oenanthe javanica), were used in this study to investigate their uranium accumulation capability. Seeds of plants, except for buttercups, were germinated and grown for three weeks in hydroponic tanks (glass; $12 \mathrm{~cm} \times 12 \mathrm{~cm} \times 8 \mathrm{~cm}$ ) with a support net for plant roots in a phytotron. The stems of buttercups were cut into $10 \mathrm{~cm}$ pieces, immersed in hydroponic glass tanks, and roots were grown for three weeks. The following plant growth conditions, which are optimal for plant germination and growth, were maintained: temperature of $25{ }^{\circ} \mathrm{C}, 70 \%$ humidity, $4000 \mathrm{Lux}$ (16 h/day), and $600 \mathrm{mg} / \mathrm{L}$ of $\mathrm{CO}_{2}$.

\subsection{Uranium Rhizofiltration Experiments}

In this study, all rhizofiltration experiments were conducted for a total of $72 \mathrm{~h}$ after sufficiently soaking the roots of the plants in a hydroponic tank $(12 \mathrm{~cm} \times 12 \mathrm{~cm} \times 8 \mathrm{~cm})$ filled with $350 \mathrm{~mL}$ contaminated water (Figure S1a). To ensure the reliability of the experimental results, the experiments were repeated three times under the same conditions for each plant. Control experiments without uranium were also performed for comparison with uranium accumulation in each plant root and shoot. After the experiments, the plants were separated into roots and leaves (Figure S1b) and pretreated by wet decomposition to analyze the 
concentration of uranium adsorbed on each part of the plant. Detailed descriptions of the wet decomposition are provided below (Section 2.3). Finally, the BCFs of uranium were calculated as the ratios of the mean uranium concentrations in the plant to the mean concentration in the groundwater. The mean differences of uranium concentrations among plant species were compared by one-way analysis of variance (ANOVA) test using SAS version 9.4 (SAS Inc., Cary, NC, USA).

2.2.1. Rhizofiltration Experiments with Different Initial Uranium Concentrations and $\mathrm{pH}$ Values

Batch rhizofiltration experiments with artificially contaminated solutions with different uranium concentrations $(15,30,80,120,180$, and $450 \mu \mathrm{g} / \mathrm{L})$ were conducted to investigate the uranium accumulation capacities of the four species. For the batch experiments, ultrapure water purified with a Mili-Q water purification system (Millipore, Molsheim, France) was titrated with a uranium standard solution $(1000 \mathrm{~g} / \mathrm{mL}$ in $1 \%(v / v)$ $\mathrm{HNO}_{3}$; Sigma-Aldrich (Saint Louis, MO, USA)).

In addition, batch rhizofiltration experiments were conducted under different $\mathrm{pH}$ conditions to investigate the changes in uranium accumulation of the plant depending on the $\mathrm{pH}$ of the water. The $\mathrm{pH}$ of the contaminated water was adjusted by adding $\mathrm{HCl}$ and $\mathrm{NaOH}$. The uranium concentrations adsorbed on the plants were compared after hydroponic cultivation under four $\mathrm{pH}$ conditions ( $\mathrm{pH} 3,5,7$, and 9). The initial uranium concentration of the contaminated water was set to $116 \mu \mathrm{g} / \mathrm{L}$.

\subsubsection{Rhizofiltration Experiment with Genuine Groundwater}

Genuine groundwater with uranium concentrations of 86 and $173 \mu \mathrm{g} / \mathrm{L}$ was sampled from two different sites in South Korea: Oesam-dong, Deajeon, and Bugok-dong, Busan. To determine the chemical properties of the groundwater used in this study, the $\mathrm{pH}$, oxidationreduction potential (ORP), dissolved oxygen (DO), electric conductivity (EC), and heavy metal concentrations were measured. Table S1 shows the chemical characteristics of the two types of genuine groundwater used for the rhizofiltration experiments.

Rhizofiltration experiments using the four plant species were carried out with two groundwater samples. The phytotron conditions and procedures of the rhizofiltration experiments were the same as those used in the previous experiments.

\subsection{Analysis of Uranium Accumulation in Plants}

To analyze the uranium accumulation in the plants after $72 \mathrm{~h}$ of rhizofiltration experiments, the plants were separated into leaves (including stems) and roots, soaked in $0.1 \%$ $\mathrm{HClO}_{4}$ solution for $3 \mathrm{~min}$ and washed with distilled water. The uranium concentration of the plant was determined by wet decomposition. In the wet decomposition process after the experiment, $3 \mathrm{~g}$ plant samples were separated into roots $(1 \mathrm{~g})$ and shoots $(2 \mathrm{~g})$ and placed in a $300 \mathrm{~mL}$ beaker to which $10 \mathrm{~mL}$ nitric acid $\left(\mathrm{HNO}_{3}\right)$ was added for $10 \mathrm{~h}$ [28]. First, acid decomposition was carried out at $180^{\circ} \mathrm{C}$ by adding $1 \mathrm{~mL}$ of hydrogen peroxide $\left(\mathrm{H}_{2} \mathrm{O}_{2}\right)$ solution to the samples until all the brown smoke was disappeared (organic decomposition). Subsequently, $20 \mathrm{~mL}$ of the ternary solution $\left(\mathrm{HNO}_{3}: \mathrm{H}_{2} \mathrm{SO}_{4}: \mathrm{HClO}_{4}=10: 1: 4\right)$, the final decomposition solution, was added and slowly heated at $160-200{ }^{\circ} \mathrm{C}$ until the solution turned pale yellow or colorless. After adjusting the volume of the final digestion solution to $10 \mathrm{~mL}$ using $0.5 \%$ nitric acid, the uranium concentration of the filtrate (filter paper: Whatman No. 40) was analyzed using inductively coupled plasma mass spectrometry (Elan 6100, FIMS 400, Perkin Elmer, Waltham, MA, USA). For the control experiment, a blank reagent without plant roots and shoots was used for the decomposition and the results were compared with those of the rhizofiltration experiments.

In this study, the bioconcentration factor $(\mathrm{BCF})$ is defined as the ratio of the uranium concentration in the plant to that in the solution. The BCF indicates an index of the capability of the plant to accumulate uranium with respect to its concentration in the solution [29]. The capability of the plant to accumulate uranium may be evaluated using the 
BCF value when compared between different accumulation periods and plant species [30]. The uranium $\mathrm{BCF}$ for each plant species can be expressed in dimensionless form as

$$
\mathrm{BCF}=\frac{\mathrm{U} \text { concentration in plant }(\mu \mathrm{g} / \mathrm{g})}{\mathrm{U} \text { concentration in solution }(\mathrm{mg} / \mathrm{L})}
$$

\subsection{Scanning Electron Microscopy and Energy-Dispersive X-ray Spectrometry}

Scanning electron microscope (SEM) and energy dispersive X-ray spectrometer (EDS) were performed to determine the uranium adsorption pattern on the plant root surface. After hydroponically cultivating the plants in $350 \mathrm{~mL}$ of artificially contaminated water (pH 5) with an initial uranium concentration of $100 \mathrm{mg} / \mathrm{L}$ for $24 \mathrm{~h}$, the root surfaces of the plants were coated with gold and SEM (HITACHI S-2700, Tokyo, Japan) and EDS (KEVEX Ltd. SIGMA, Newark, DF, USA) analysis were carried out using a voltage of $20 \mathrm{kV}$ and 5000-fold magnification. In the SEM image of the root surface, three spots with solid phase crystals were randomly selected and subjected to EDS analysis to determine the presence of uranium on the plant root surface.

\section{Results and Discussion}

\subsection{Rhizofiltration Experiments with Different Initial Uranium Concentrations and $p H$ Values}

The results for the uranium accumulation in the roots and shoots of four plant species for six different uranium solutions $(15,30,80,120,180$, and $450 \mu \mathrm{g} / \mathrm{L})$ are shown in Figure 1. The uranium contents of the roots and shoots of all four plant species increase with increasing uranium concentration in the solution. At all solution concentrations, most of the uranium is accumulated in the roots, with an average of $98 \%$, despite the small volume and weight of roots compared with those of the shoots. At an initial uranium concentration of $15 \mu \mathrm{g} / \mathrm{L}$, the highest uranium concentration of $32.3 \mu \mathrm{g} / \mathrm{g}$ dry weight (DW) was observed in the roots of Raphanus sativus L. (Figure 1a). The uranium concentrations in the roots of Brassica campestris L. and Lactuca sativa L. are 26.8 and $18.4 \mu \mathrm{g} / \mathrm{g}$ DW and Oenanthe javanica contains the lowest amount of uranium $(17.9 \mu \mathrm{g} / \mathrm{g} \mathrm{DW})$. At the maximum initial uranium concentration $(450 \mu \mathrm{g} / \mathrm{L})$, the uranium accumulation in the roots of Brassica campestris L. and Raphanus sativus L. is high $(1321.9 \pm 125.2$ and $1215.8 \pm 80 \mu \mathrm{g} / \mathrm{g} \mathrm{DW}$, respectively). The roots of Lactuca sativa L. and Oenanthe javanica contain lower amounts of uranium at $699.1 \pm 35.4$ and $548.1 \pm 66.8 \mu \mathrm{g} / \mathrm{g}$ DW, respectively. The amount of uranium accumulated in the leaves of all the species is very low, less than $10 \mu \mathrm{g} / \mathrm{g}$ DW, with an initial uranium concentration in the solution from $15 \mu \mathrm{g} / \mathrm{L}$ to $180 \mu \mathrm{g} / \mathrm{L}$ (Figure 1b). Even at a high concentration of uranium $(450 \mu \mathrm{g} / \mathrm{L})$ in the solution, the uranium accumulation in the leaves of all species is on average $14.4 \mu \mathrm{g} / \mathrm{g}$ DW. Lactuca sativa L. leaves show the highest uranium concentration of $23.7 \pm 14.5 \mu \mathrm{g} / \mathrm{g} \mathrm{DW}$, which is $\sim 3.8$ times higher than that of Oenanthe javanica leaves $(6.2 \pm 0.8 \mu \mathrm{g} / \mathrm{g}$ DW). For different initial concentrations in the solution, there was a significant difference in the uranium accumulation in both shoots and roots of all species, based on the result of the statistical test by ANOVA $(p<0.05)$ (Table S2), indicating that a higher uranium concentration in the solution leads to grater uranium accumulation in the roots of all species.

The uranium BCFs for each plant calculated based on the rhizofiltration experiments with various initial uranium concentrations in the solution are illustrated in Figure 2. The uranium $B C F$ values of the four species depend on the initial uranium concentration in the solution. The uranium BCFs of Brassica campestris L. and Raphanus sativus L. are high (1147.5-2968.4 and 2146.7-3578.3, respectively), whereas those of Lactuca sativa L. and Oenanthe javanica are low (863.7-1860.7 and 606-1444.4, respectively). The average BCF value of Raphanus sativus $\mathrm{L}$. is 2683.5, which is the highest among the four species, followed by the BCF of Brassica campestris L. (2141.5), Lactuca sativa (1447.2), and Oenanthe javanica (1076). 
(a)

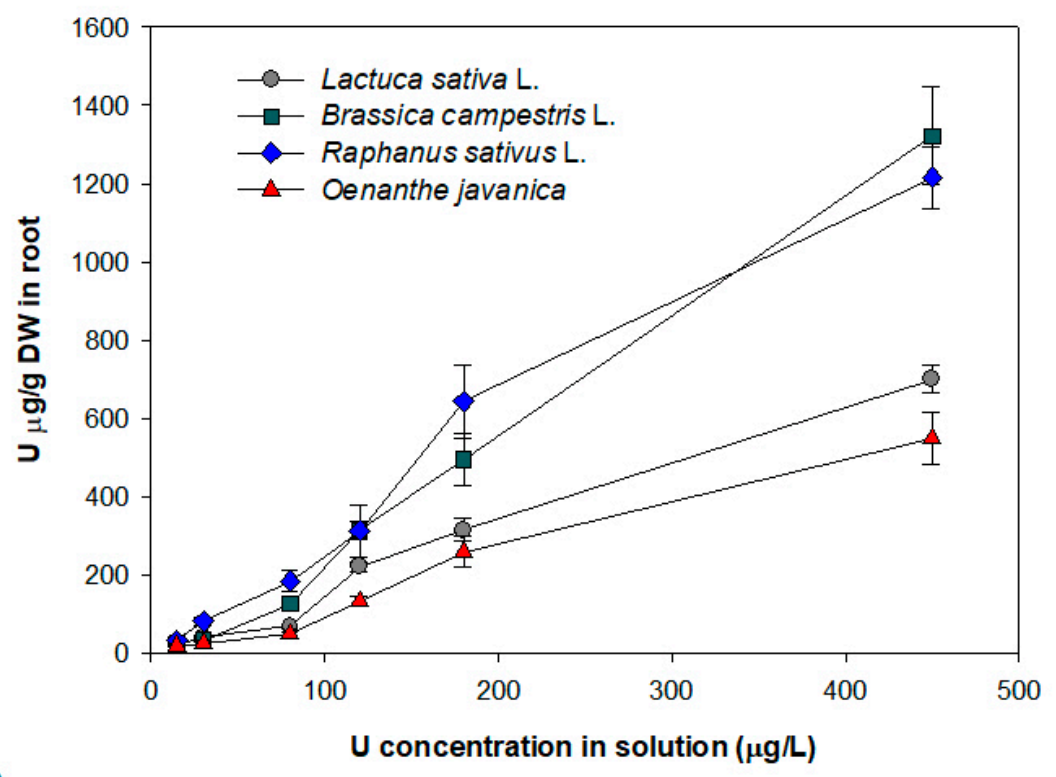

(b)

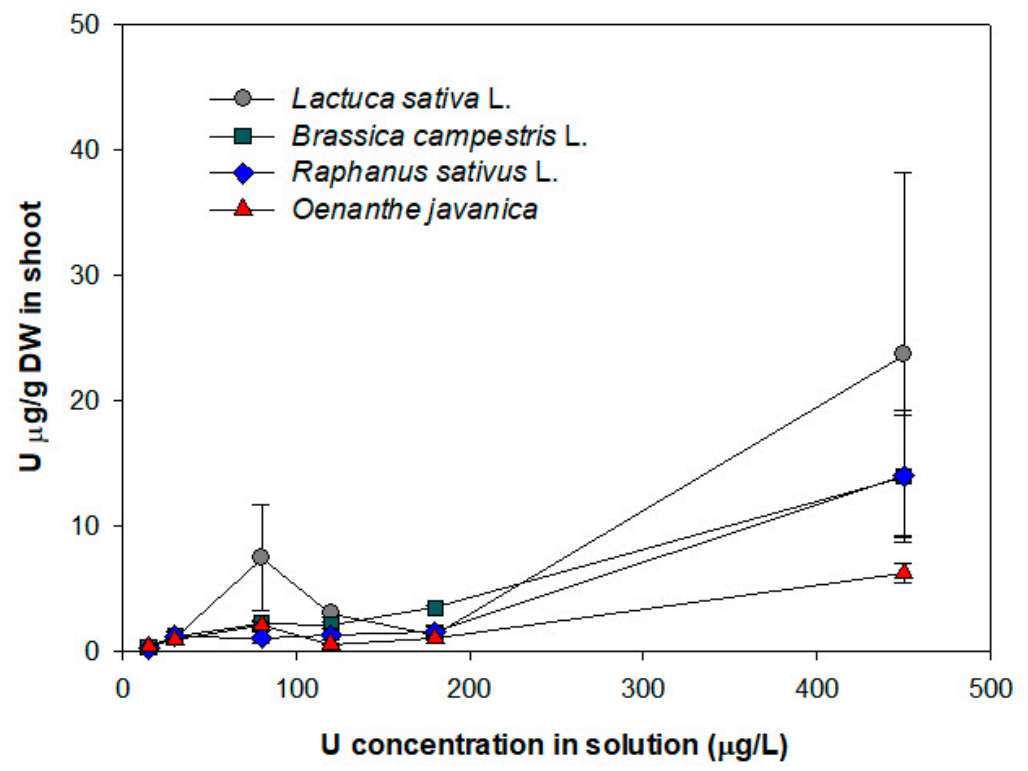

Figure 1. Uranium accumulation in the roots (a) and shoots (b) of four different plant species after $72 \mathrm{~h}$ of treatment with solutions with different concentrations $(15,30,80,120,180$, and $450 \mu \mathrm{g} / \mathrm{L})$.

The uranium BCF values of the four species depending on the $\mathrm{pH}$ conditions are shown in Figure 3. The average uranium BCF values of all species are 6820.9 at $\mathrm{pH} 3$, 2121.5 at $\mathrm{pH} 5,365.9$ at $\mathrm{pH}$ 7, and 422.1 at $\mathrm{pH}$ 9, indicating that a lower $\mathrm{pH}$ leads to greater uranium accumulation in the plants (Table S3). In ANOVA analysis, statistically significant differences were found in the uranium accumulation in both shoots and roots of all species with different $\mathrm{pH}$ conditions $(p<0.05)$ (Table S2). The uranium BCF values of Raphanus sativus L. and Brassica campestris L. under acidic condition (pH 3) are 11061.3 and 11580.3, and their uranium concentrations in the roots are 1320.2 and $1259.0 \mu \mathrm{g} / \mathrm{g}$, respectively. They are significantly higher than the values under other $\mathrm{pH}$ conditions. Similar results were previously reported for sunflower and bean plants at $\mathrm{pH} 3$ and $\mathrm{pH} 5$ [14,24,27]. Under acidic conditions below $\mathrm{pH} 5$, the dissolved species of uranium in the solution do not form bonds with other anions (e.g., $\mathrm{OH}$ and $\mathrm{CO}_{3}{ }^{2-}$ ) but mainly exist in the form of the cationic $\mathrm{UO}_{2}{ }^{2+}$ (uranyl cation). It has been speculated that the uranium BCF of the plants 
significantly increases due to the adsorption of the uranyl cation to the carboxyl group $\left(\mathrm{COO}^{-}\right)$of the negatively charged plant cell wall $[16,17]$.

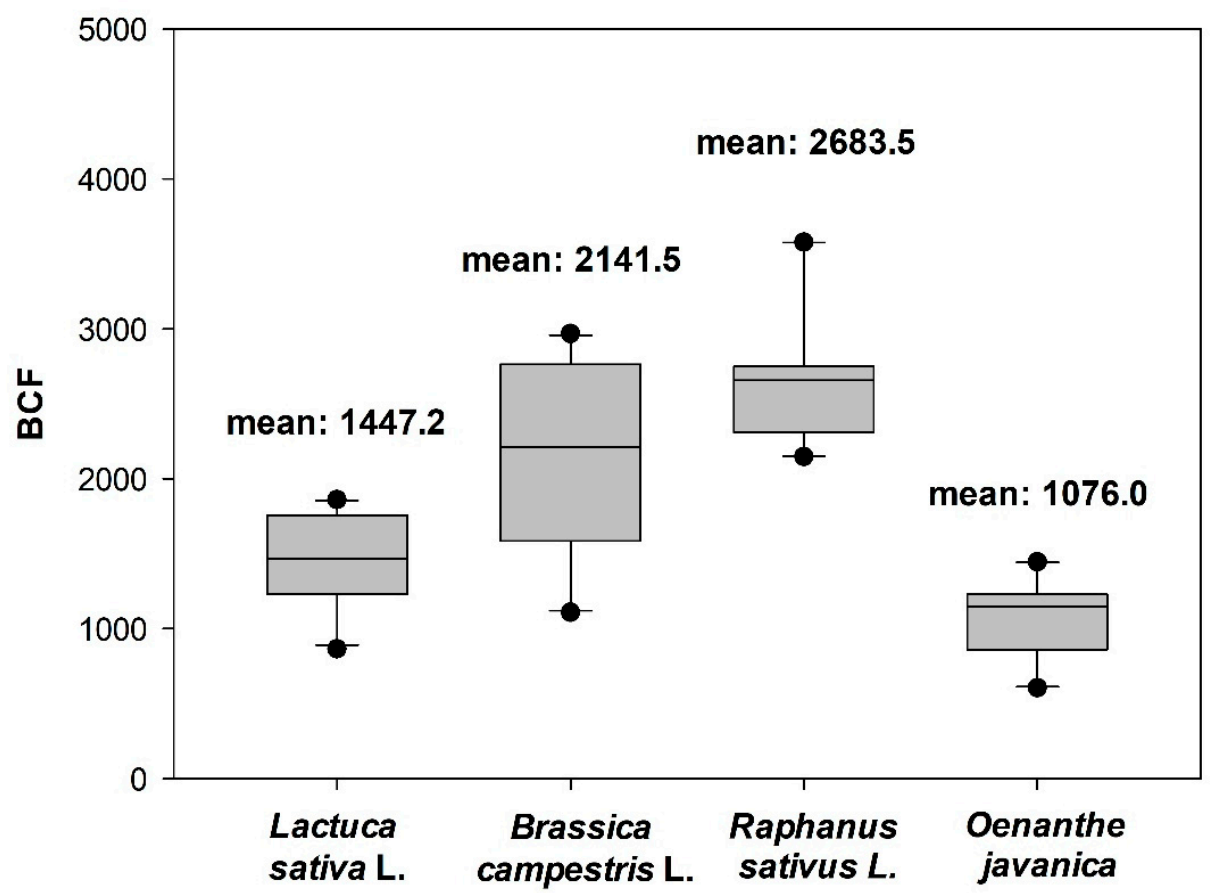

Figure 2. Box-and-whisker plot of bioaccumulation factors of four species in artificial solutions with different initial uranium concentrations $(15,30,80,120,180$, and $450 \mu \mathrm{g} / \mathrm{L})$ after $72 \mathrm{~h}$ of treatment.

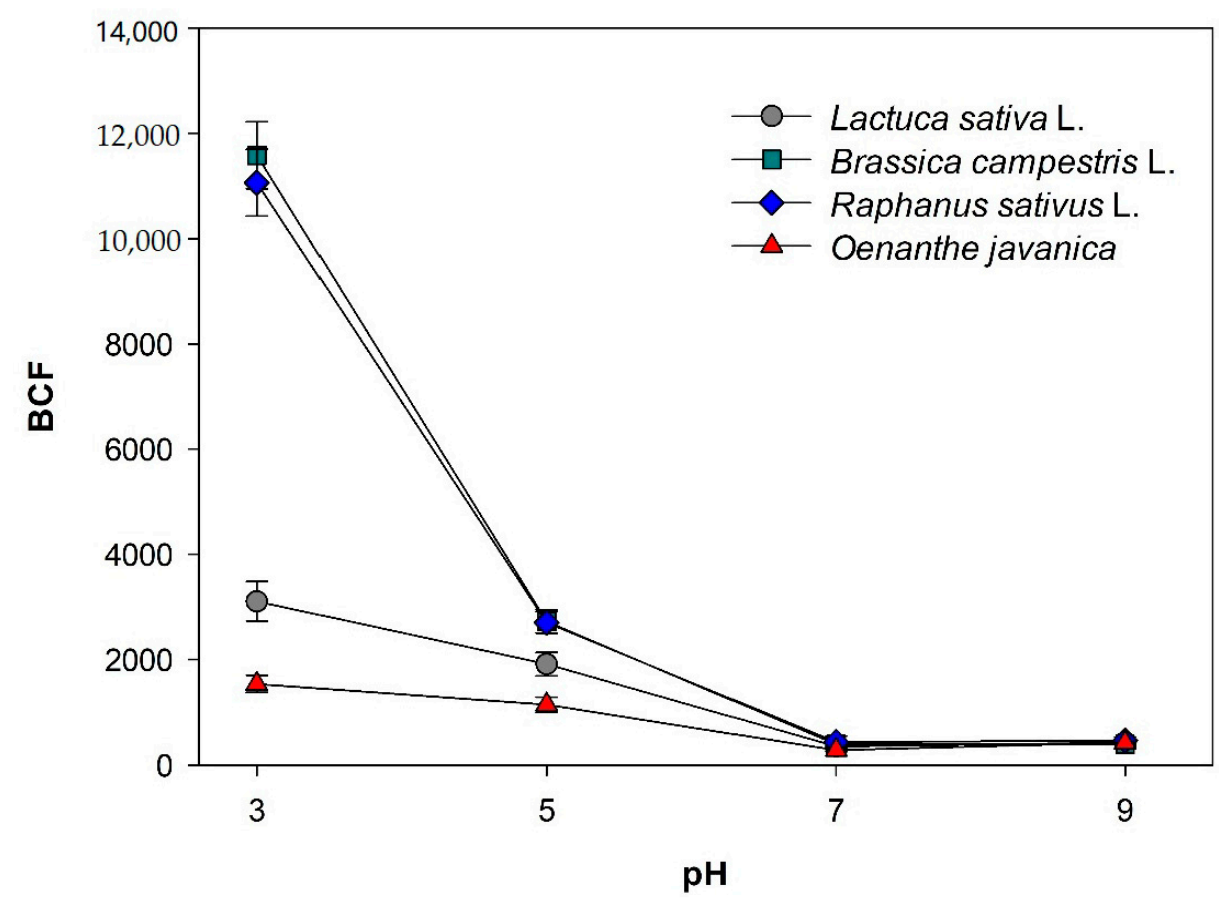

Figure 3. Uranium bioconcentration factors of four different plant species in artificially contaminated solutions with four different $\mathrm{pH}$ values after $72 \mathrm{~h}$ treatment.

\subsection{Rhizofiltration Experiment with Genuine Groundwater}

The uranium accumulation and removal efficiency for the four species based on the groundwater are shown in Table S4. For the Oesam-dong groundwater with the 
uranium concentration of $83 \mu \mathrm{g} / \mathrm{L}$, the ratios (accumulation efficiency) of the uranium mass in solution to the uranium accumulated mass in each plant were as follows: Raphanus sativus L. (88.8\%), Brassica campestris L. (82.9\%), Lactuca sativa (66.1\%), and Oenanthe javanica (32.6\%). For the Bugok-dong groundwater with the uranium concentration of $173 \mu \mathrm{g} / \mathrm{L}$, the accumulation efficiency of Raphanus sativus L. is the highest (82.8\%), followed by Brassica campestris L. (77\%), Lactuca sativa $(46.9 \%)$, and Oenanthe javanica $(29.5 \%)$. The average uranium BCF of Raphanus sativus L. (1692.4) from the two rhizofiltration experiments is the highest among the four plants, followed by Brassica campestris L. (1160.2), Lactuca sativa (422.8) and Oenanthe javanica (170.5) (Figure 4). This order is the same as that of the results of the rhizofiltration experiments with artificially contaminated groundwater. For the Oesam-dong groundwater, the uranium BCF can be ranked as follows: Raphanus sativus L. (1684.7) > Brassica campestris L. (781.1) > Lactuca sativa (487.6) > Oenanthe javanica (213.5). In the groundwater of Bugok-dong, the uranium BCF of Raphanus sativus L. is the highest (1700.1), followed by Brassica campestris L. (1539.3), Lactuca sativa (358), and Oenanthe javanica (127.5). Because chemical characteristics of genuine groundwater were quite different from those of artificial groundwater, the uranium BCFs in genuine groundwater were not as high as those of the artificially contaminated groundwater. However, these results confirm that Raphanus sativus L. has a remarkable potential to accumulate uranium from contaminated groundwater despite the different water characteristics and ionic strength caused by competitive ions in the genuine groundwater.

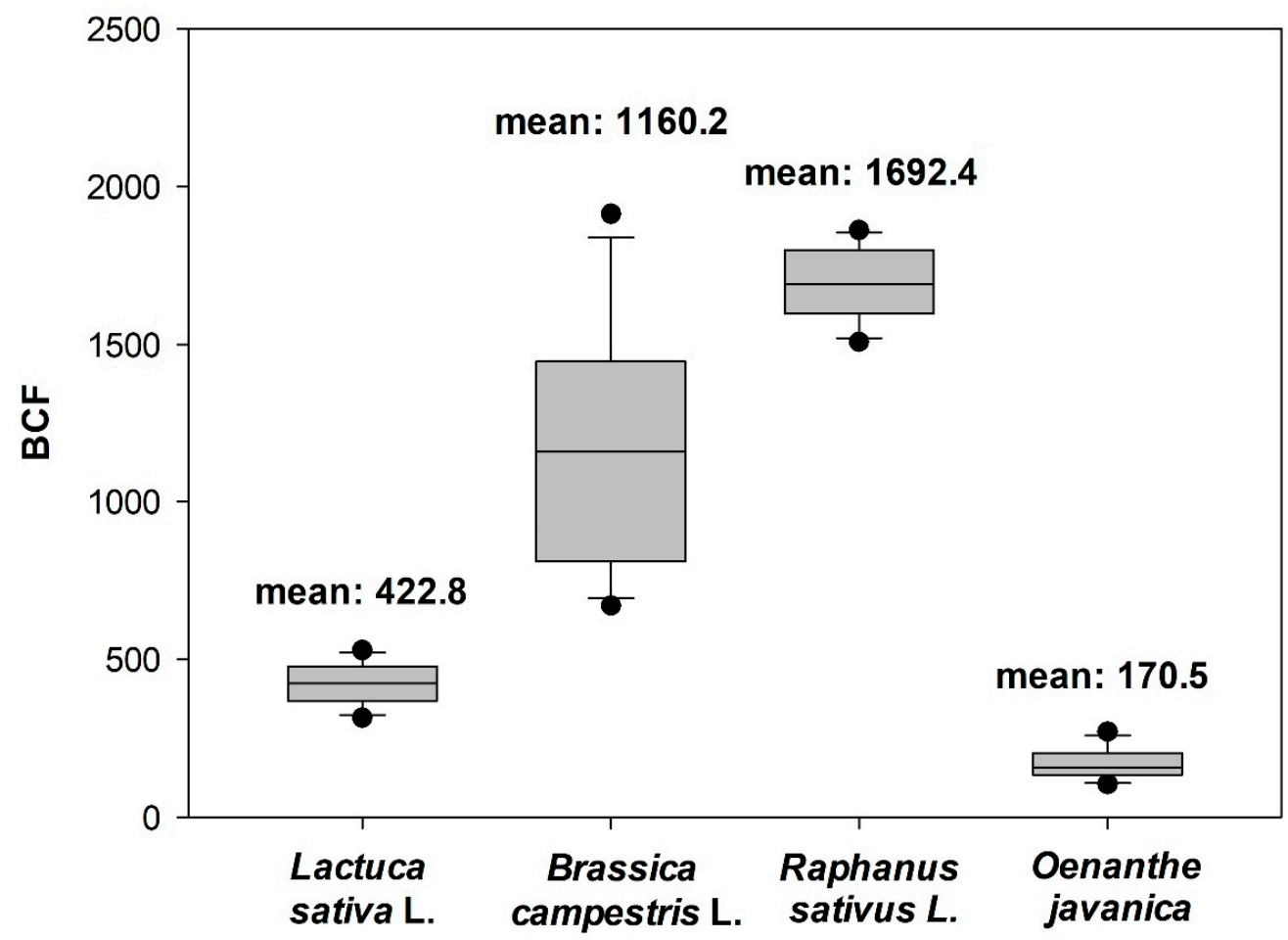

Figure 4. Box-and-whisker plot of bioaccumulation factors of four plant species in genuine groundwater samples with different initial uranium concentrations ( 83 and $173 \mu \mathrm{g} / \mathrm{L}$ ) after $72 \mathrm{~h}$ of treatment.

\subsection{SEM/EDS Analysis of Uranium Adsorbed on Plant Roots}

The results of SEM and EDS analyses, which confirm the adsorption of uranium onto the roots of Raphanus satious L. after the uranium rhizofiltration experiment, are shown in Figure 5. The SEM micrographs provide direct optical evidence for the uranium adsorption onto the surface of the plant roots. Many clusters of small white particles (Figure 5a) and a relatively big white crystal (Figure $5 b$ ) can be observed. The EDS spectra of the white crystals in the white circle shown in Figure 5a,b were obtained. The uranium peaks in the EDS spectra indicate significantly high uranium concentrations, accounting for $79.6 \%$ and 
$68.2 \%$ of the total component weight, respectively (Figure $5 c, d$ ). These findings suggest that adsorption or precipitation may be the dominant mechanism of uranium removal from groundwater. Considering that the phosphate contents account for $17.4 \%$ and $18 \%$ of the total component weight based on the EDS analysis (Figure 5c,d), the white crystals are presumed to be phosphate complexes such as $\mathrm{UO}_{2} \mathrm{HPO}_{4}{ }^{0}$ and $\mathrm{UO}_{2}\left(\mathrm{HPO}_{4}\right)_{2}{ }^{2-}[11,31]$. These findings are consistent with the results of previous studies in which optical evidence of white particles was provided using SEM and EDS analyses; the authors suggested that adsorption on the root surface of sunflower and bean is the dominant mechanism for uranium removal from the solution [24,27]. However, the size of the white particles in the SEM micrographs was much smaller $(<1 \mu \mathrm{m})$ than those of the particles $(>10 \mu \mathrm{m})$ observed in this study and the uranium concentration of the particles was also much smaller $(<26 \%$ of the total composition weight) than that determined in this study ( $>68 \%$ of the total composition weight) $[24,27]$.
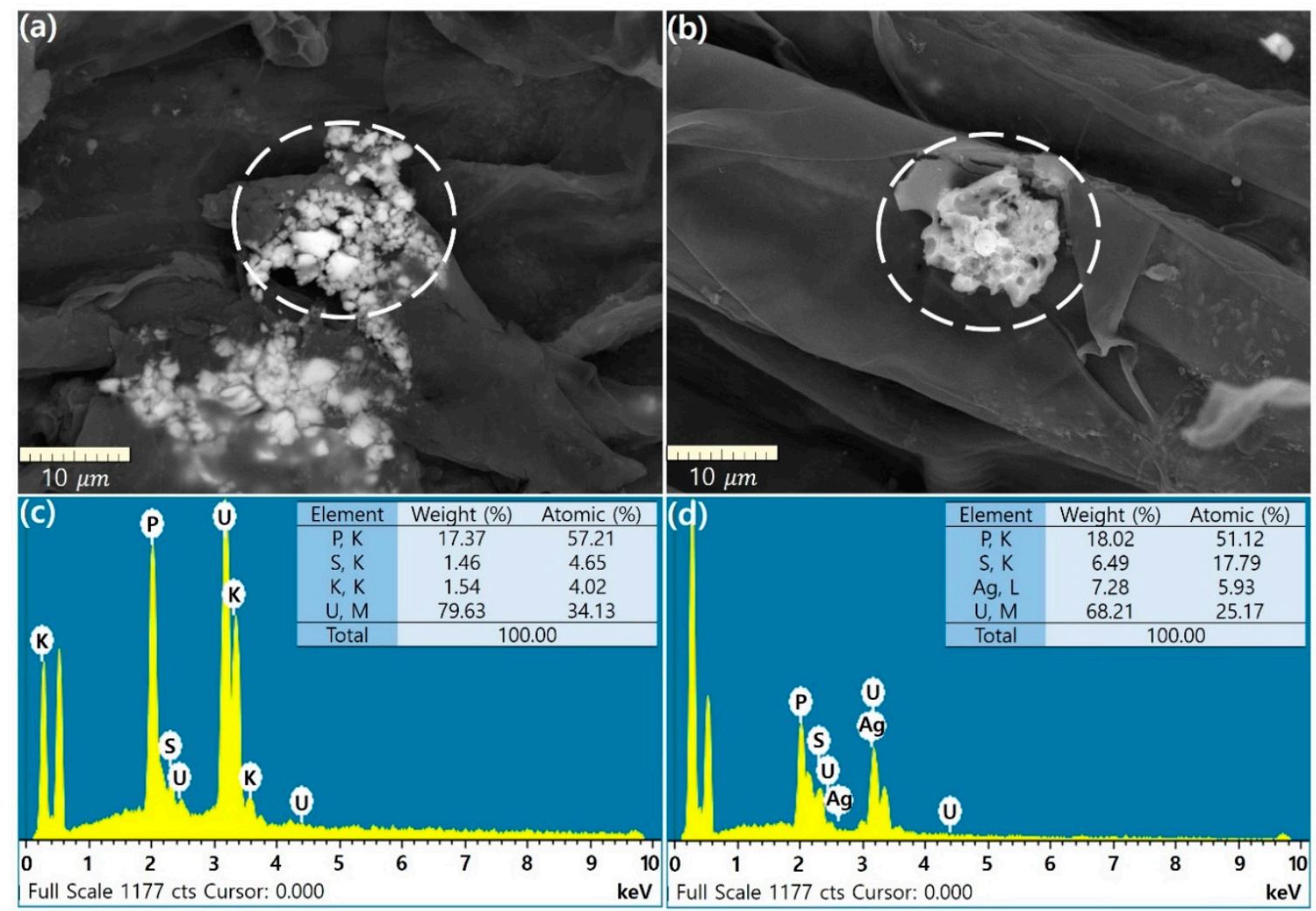

Figure 5. SEM micrographs of Raphanus sativus L. roots after rhizofiltration and EDS spectra for a cluster of white crystalline particles $(\mathbf{a}, \mathbf{c})$ and a big white crystal particle $(\mathbf{b}, \mathbf{d})$ in the dashed white circle.

\subsection{Uranium BCF Trends in Plants}

The uranium BCFs reflect the capacities of plants to accumulate uranium from a solution. Because the BCF values depend on the uranium concentrations of the individual plants and solution, they allow a comparison of the uranium accumulation in different plant species $[20,22,23,25,27,32-39]$. Note that the uranium BCF values of previous studies are compared with the results of this study in Figures 6-8. The rhizofiltration time required for bioaccumulation to remove uranium in artificially contaminated solutions significantly varies among the plants in previous studies, as shown in Figure 6. The BCF values are the highest in studies using longer reaction times (more than nine days; [32-35]). Although the reaction time used to determine the $\mathrm{BCF}$ values in this study is three days, the four species used in this study show intermediate BCFs ranging from $>1000$ to $<3000$. The BCF of Raphanus sativus L. (2683.5) is more than three times higher than that reported for Phaseolus 
vulgaris L. var. vulgaris (889.3) by Yang et al. (2015) [27], who used the same reaction time for the rhizofiltration experiments (three days).

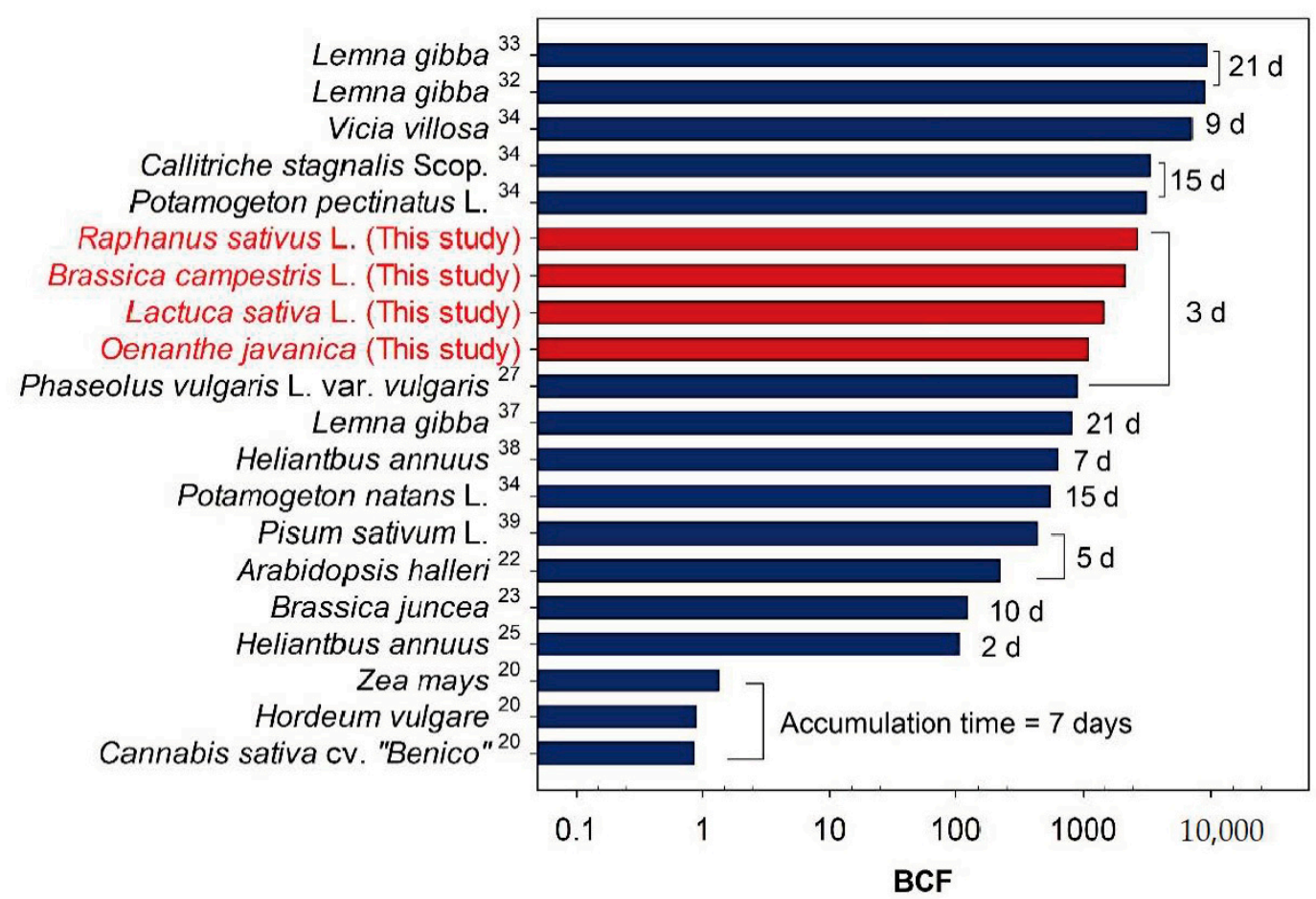

Figure 6. Average uranium BCFs of various plants after rhizofiltration experiments using artificially contaminated solution. The BCF values and accumulation times were obtained from previous studies.

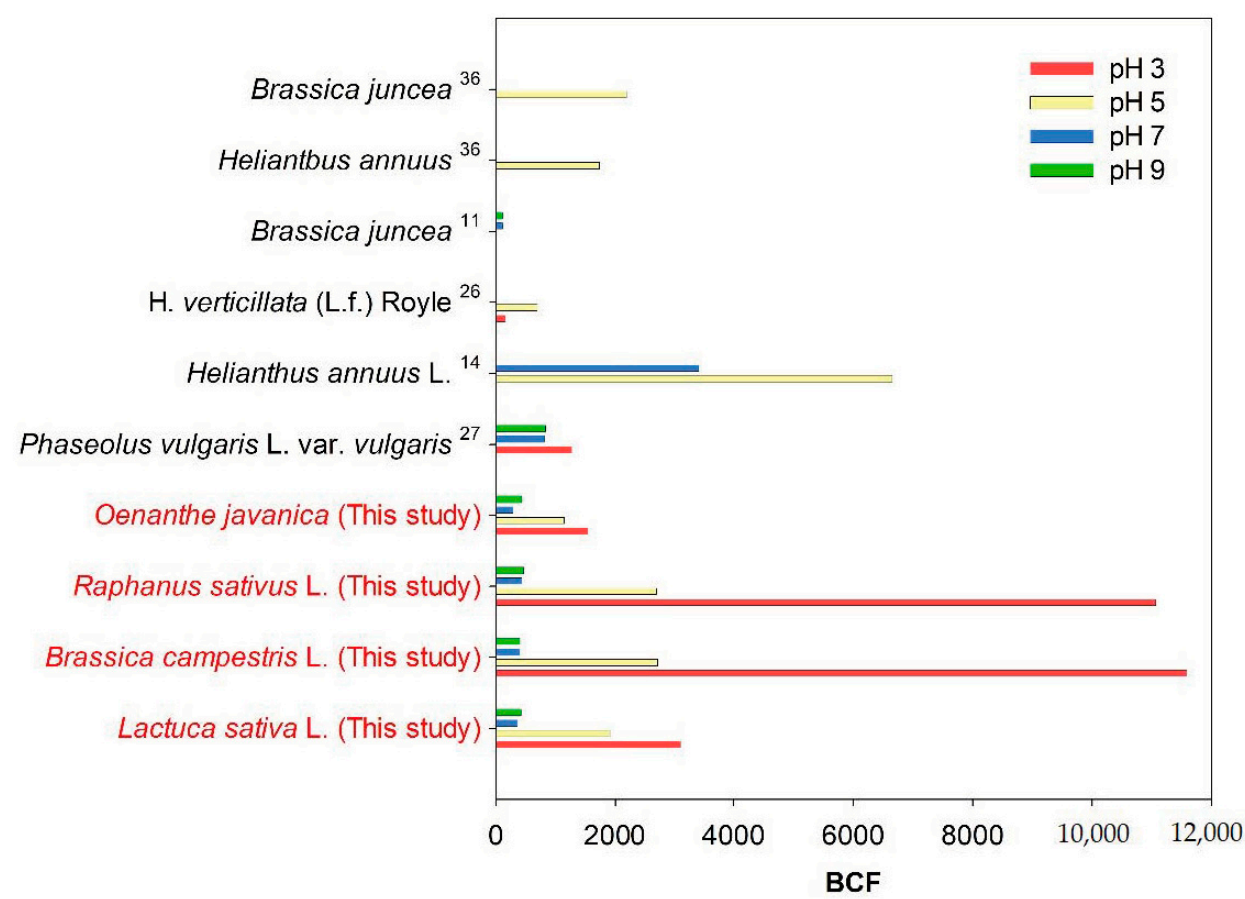

Figure 7. Average uranium BCFs of various plants after accumulation experiments using solutions with different $\mathrm{pH}$ values. The BCF values were obtained from previous studies. 


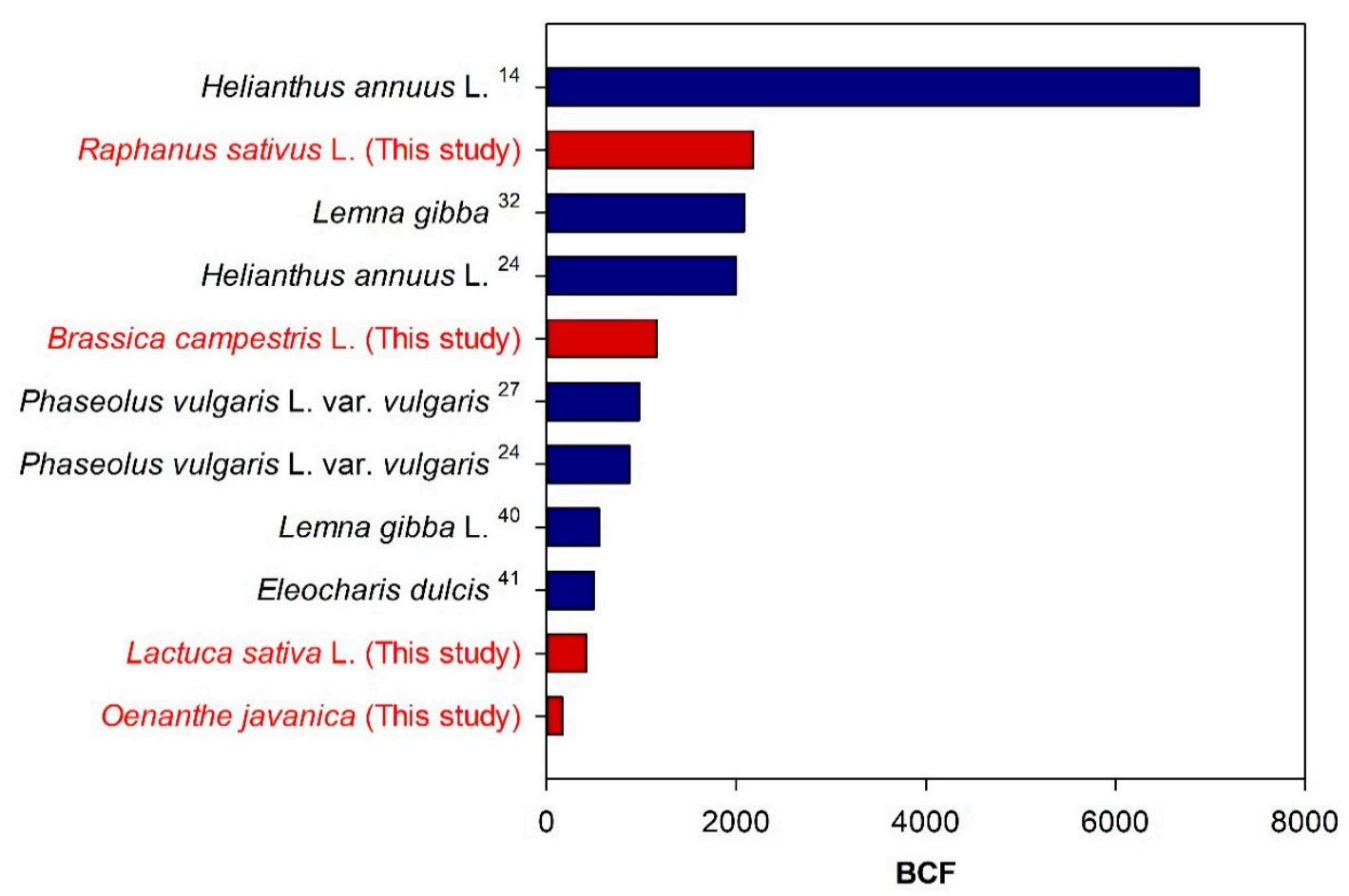

Figure 8. Average uranium $\mathrm{BCF}$ s of various plants after accumulation experiments using genuine groundwater and surface water. The BCF values were obtained from previous studies.

The dependency of the BCF on $\mathrm{pH}$ conditions for previous studies and this study are summarized in Figure $7[11,14,26,27,36]$. At a pH of 5 or higher, the BCF values of the four plants in this study are lower than those reported for Phaseolus vulgaris L. var. vulgaris ( $\mathrm{pH} 9=831.6$, pH $7=808.5$ ) by Yang et al. (2015) [27] and Helianthus annuus L. ( $\mathrm{pH} 7=3406.8, \mathrm{pH} 5=6654.5)$ by Dushenkov et al. (1997) [14]. However, the BCF values determined for Raphanus sativus L. and Brassica campestris L. at a $\mathrm{pH}$ of 3 in this study are 11,061.3 and 11,580.3, respectively, which are remarkably higher than those of plants reported in previous studies. These results suggest that the uranium accumulation in plants is enhanced under acidic conditions ( $\mathrm{pH} 3-5)$. In addition, the results show that Raphanus sativus L. and Brassica campestris L. can be employed to remove uranium using rhizofiltration, even in acidic environments such as acid mine drainage.

The uranium BCF values determined for various plants during rhizofiltration experiments using genuine ground- and surface water are summarized in Figure 8; they range from $>10^{2}$ to $<10^{4}[14,24,27,32,40,41]$. Even discounting the BCF of approximately 7000 reported for Helianthus annuus L. by Dushenkov et al. (1997) [14], who conducted rhizofiltration experiments under continuous injection of uranium-contaminated surface water at a flow rate of $1.05 \mathrm{~L} / \mathrm{min}$ for 14 days, Raphanus sativus $\mathrm{L}$. in this study, Lemna gibba (Mkandawire et al., 2004b) [33], and Helianthus annuus L. (Lee and Yang, 2010) [24] exhibit average BCFs of 2179, 2085, and 2000, respectively, indicating their great rhizofiltration ability. The BCF of Raphanus sativus L. in this study is more than two times higher than the values reported for Phaseolus vulgaris L. var. vulgaris by Lee and Yang (2010; 875) [24] and Yang et al. $(2015 ; 976)$ [27], who used the same experiment time of three days.

However, this work used a simplified approach to compare between the obtained and measured $\mathrm{BCF}$ values. Although the value of BCF provides robust estimates of uranium accumulation capacity for plants from a solution, the associated parameters used in previous studies such as different initial concentrations, exposure times, and competitive ions in a solution varied. There is a possibility that longer exposure periods and high uranium concentration in a solution may lead to physiological damage that results in a reduced ability to adsorb contaminants and allows the adsorbed contaminants 
to be excreted again. In addition, this work posits that chemical characteristics of the genuine groundwater used in this study are similar to those used in previous studies. Various assessments are needed to evaluate the relationship between BCFs and chemical characteristics, such as competitive adsorption of cations onto the root surface.

\section{Conclusions and Implications}

Based on the results of the rhizofiltration experiments with artificially contaminated solutions with different initial uranium concentrations, the highest uranium accumulation is observed for Raphanus sativus L., with an average BCF of 2683.5, followed by Brassica campestris L., Lactuca sativa, and Oenanthe javanica. At all uranium concentrations, the uranium accumulations in the roots of all species are two orders of magnitude higher than that in the shoots. Under acidic conditions ( $\mathrm{pH} 3$ ), the BCF values of both Raphanus satious L. and Brassica campestris L. are more than 4 times higher than those at $\mathrm{pH} 5$ and more than 25 times higher than those at $\mathrm{pH} 7$ and 9. The results of the SEM and EDS analyses using the roots of Raphanus sativus L. demonstrate that the primary rhizofiltration mechanisms are the adsorption and precipitation of uranium phosphate onto the root surface. When compared with uranium BCFs of various plant species from previous studies, Raphanus sativus L. demonstrates a remarkable potential for uranium accumulation with a high tolerance to low $\mathrm{pH}$ and high uranium concentrations in the solution.

The results of various rhizofiltration experiments confirm the outstanding uranium accumulation capacities of Lactuca sativa, Brassica campestris L., Raphanus sativus L., and Oenanthe javanica, which have not been used in previous uranium accumulation studies. Among the four species, Raphanus sativus L. is a plant species capable of accumulating a large amount of uranium in a relatively short time. Although this work conducted laboratory-scale experiments, the rhizofiltration approach can be applied to remove uranium at larger scales, such as continuous clean-up rhizofiltration systems; each rhizofiltration reservoir is connected to another as a series circuit $[14,42]$. For example, in the rhizofiltration experiment with uranium solution $(116 \mu \mathrm{g} / \mathrm{L})$ under the acidic condition for 72 h, $0.1 \mathrm{~g}$ DW of Raphanus sativus L. roots accumulated approximately $40 \mu \mathrm{g}$ of uranium mass from the solution. Assuming $1000 \mathrm{~L}$ of groundwater having a uranium concentration of $116 \mu \mathrm{g} / \mathrm{L}$ is treated using the continuous clean-up system, approximately $300 \mathrm{~g} \mathrm{DW}$ of Raphanus sativus L. roots would be sufficient to remove uranium in the groundwater. Therefore, it can be applied for uranium removal studies in the future. In the future, potential harmful effects of uranium accumulation in plants on human health should be studied. In contrast to the plants utilized in previous studies, the four plant species used in this study are all edible crops. If local uranium-contaminated groundwater is used as water source for these plants, humans will be exposed to high levels of uranium. Hence, more research is needed regarding the uranium contamination of crops and vegetables and the expected uranium intake.

Supplementary Materials: The following are available online at https:/ / www.mdpi.com/2075-163 X/11/1/41/s1, Figure S1: photographs of Lactuca sative L., Brassica campestirs L., Raphanus sativus L., and Oenanthe javanica grown for 4 weeks in the phytotron; Table S1: chemical properties of genuine groundwater samples from two sites; Table S2: the results of one-way ANOVA analysis for uranium accumulation in four plant species with the different initial concentrations and $\mathrm{pH}$ values in the solution; Table S3: Uranium concentration in roots and shoots of Lactuca sativa L., Brassica campestris L., Raphanus sativus L., and Oenanathe javanica at four different $\mathrm{pH}$ values. Each point represents the mean \pm standard deviation of triplicates, Table S4: uranium concentration in roots and shoots and removal efficiency of four different plants exposed to two genuine groundwaters (Oesam-dong $=80 \mu \mathrm{g} / \mathrm{L}$, Bugok-dong $=173 \mu \mathrm{g} / \mathrm{L})$.

Author Contributions: Writing-original draft preparation, Y.H. and M.Y.; formal analysis, Y.H and J.L.; investigation, Y.H.; conceptualization, M.L., J.L. and M.Y.; software, J.P., C.K., and J.L.; visualization, J.P., C.K., and J.L.; writing-review and editing, J.L. and M.Y.; supervision, M.L. and M.Y; funding acquisi-tion, M.L. All authors have read and agreed to the published version of the manuscript. 
Funding: This research was funded by the grant (2019002470002) from Korea Ministry of Environment as "The SEM (Subsurface Environmental Management) projects" and by the Basic Research Program through the National Research Foundation of Korea (NRF) funded by the MSIT (2020R1F1A1072122).

Institutional Review Board Statement: Not applicable.

Informed Consent Statement: Not applicable.

Data Availability Statement: Data is contained within the article or supplementary material..

Acknowledgments: The authors are grateful to researchers at Environmental Hydrogeology Laboratory (EHL) in Pukyong National University, South Korea for their valuable feedback, suggestions, and discussions.

Conflicts of Interest: The authors declare no conflict of interest.

\section{References}

1. Antonkiewicz, J.; Jasiewicz, C. The use of plants accumulating heavy metals for detoxication of chemically polluted soils. Electron. J. Polish Agric. Univ. 2002, 5, 121-143. [CrossRef]

2. Zhu, Y.; Yu, H.; Wang, J.; Fang, W.; Yuan, J.; Yang, Z. Heavy Metal Accumulations of 24 Asparagus Bean Cultivars Grown in Soil Contaminated with Cd Alone and with Multiple Metals (Cd, Pb, and Zn). J. Agric. Food Chem. 2007, 55, 1045-1052. [CrossRef] [PubMed]

3. Liu, W.; Zhou, Q.; Zhang, Z.; Hua, T.; Cai, Z. Evaluation of Cadmium Phytoremediation Potential in Chinese Cabbage Cultivars. J. Agric. Food Chem. 2011, 59, 8324-8330. [CrossRef] [PubMed]

4. $\quad$ Ma, T.; Zhou, L.; Chen, L.; Li, Z.; Wu, L.; Christie, P.; Luo, Y. Oxytetracycline Toxicity and Its Effect on Phytoremediation by Sedum plumbizincicola and Medicago sativain Metal-Contaminated Soil. J. Agric. Food Chem. 2016, 64, 8045-8053. [CrossRef] [PubMed]

5. Gramss, G.; Voigt, K.-D. Regulation of the mineral concentrations in pea seeds from uranium mine and reference soils diverging extremely in their heavy metal load. Sci. Hortic. 2015, 194, 255-266. [CrossRef]

6. Wang, N.; Wei, Q.; Yan, T.; Pan, Z.; Liu, Y.; Peng, S. Improving the boron uptake of boron-deficient navel orange plants under low boron conditions by inarching boron-efficient rootstock. Sci. Hortic. 2016, 199, 49-55. [CrossRef]

7. Beveridge, T.J.; Murray, R.G. Sites of metal deposition in the cell wall of Bacillus subtilis. J. Bacteriol. 1980, 141, 876-887. [CrossRef]

8. Suzuki, Y.; Kelly, S.D.; Kemner, K.M.; Banfield, J.F. Nanometre-size products of uranium bioreduction. Nat. Cell Biol. 2002, 419, 134. [CrossRef]

9. Katsoyiannis, I.A.; Althoff, H.W.; Bartel, H.; Jekel, M. The effect of groundwater composition on uranium(VI) sorption onto bacteriogenic iron oxides. Water Res. 2006, 40, 3646-3652. [CrossRef]

10. Pabalan, R.T.; Turner, D.R. Uranium(6+) sorption on montmorillonite: Experimental and surface complexation modeling study. Aquat. Geochem. 1997, 2, 203-226. [CrossRef]

11. Ebbs, S.D.; Brady, D.; Kochian, L.V. Role of uranium speciation in the uptake and translocation of uranium by plants. J. Exp. Bot. 1998, 49, 1183-1190. [CrossRef]

12. Cornish, J.E. Evaluation of in situ phytoremediation of uranium-contaminated soils in Ohio and Montana. In Proceedings of the Hazardous Management'95 Conference Proceeding, Tuscon, AZ, USA, 26 February-3 March 1995.

13. Dushenkov, V.; Kumar, P.B.A.N.; Motto, H.; Raskin, I. Rhizofiltration: The Use of Plants to Remove Heavy Metals from Aqueous Streams. Environ. Sci. Technol. 1995, 29, 1239-1245. [CrossRef] [PubMed]

14. Dushenkov, S.; Vasudev, D.; Kapulnik, Y.; Gleba, D.; Fleisher, D.; Ting, K.C.; Ensley, B. Removal of Uranium from Water Using Terrestrial Plants. Environ. Sci. Technol. 1997, 31, 3468-3474. [CrossRef]

15. Willey, N.; Collins, C. Phytoremediation of soil contaminated with low concentration of radionuclides. Water Air Soil Pollut. 1996, 88, 167-176.

16. Langmuir, D. Aqueous Environmental Geochemistry; Prentice Hall: Upper Saddle River, NJ, USA, 1997.

17. Waite, T.; Davis, J.; Payne, T.; Waychunas, G.; Xu, N. Uranium(VI) adsorption to ferrihydrite: Application of a surface complexation model. Geochim. Cosmochim. Acta 1994, 58, 5465-5478. [CrossRef]

18. Ebbs, S.D.; Brady, D.; Norvell, W.; Kochian, L.V. Uranium Speciation, Plant Uptake, and Phytoremediation. In Environmental and Pipeline Engineering 2000; American Society of Civil Engineers (ASCE): Reston, VA, USA, 2000; pp. 466-475.

19. Serre, N.B.; Alban, C.; Bourguignon, J.; Ravanel, S. Uncovering the physiological and cellular effects of uranium on the root system of Arabidopsis thaliana. Environ. Exp. Bot. 2019, 157, 121-130. [CrossRef]

20. Soudek, P.; Petrova, S.; Benešová, D.; Dvorakova, M.; Vanek, T. Uranium uptake by hydroponically cultivated crop plants. J. Environ. Radioact. 2011, 102, 598-604. [CrossRef]

21. Stojanović, M.D.; Mihajlović, M.L.; Milojković, J.; Lopičić, Z.R.; Adamović, M.; Stanković, S. Efficient phytoremediation of uranium mine tailings by tobacco. Environ. Chem. Lett. 2012, 10, 377-381. [CrossRef]

22. Viehweger, K.; Geipel, G. Uranium accumulation and tolerance in Arabidopsis halleri under native versus hydroponic conditions. Environ. Exp. Bot. 2010, 69, 39-46. [CrossRef] 
23. Eapen, S.; Suseelan, K.; Tivarekar, S.; Kotwal, S.; Mitra, R. Potential for rhizofiltration of uranium using hairy root cultures of Brassica juncea and Chenopodium amaranticolor. Environ. Res. 2003, 91, 127-133. [CrossRef]

24. Lee, M.; Yang, M. Rhizofiltration using sunflower (Helianthus annuus L.) and bean (Phaseolus vulgaris L. var. vulgaris) to remediate uranium contaminated groundwater. J. Hazard. Mater. 2010, 173, 589-596. [CrossRef] [PubMed]

25. Tomé, F.V.; Rodríguez, P.B.; Lozano, J. Elimination of natural uranium and 226 Ra from contaminated waters by rhizofiltration using Helianthus annuus L. Sci. Total. Environ. 2008, 393, 351-357. [CrossRef] [PubMed]

26. Srivastava, S.; Bhainsa, K.; D'Souza, S.F. Investigation of uranium accumulation potential and biochemical responses of an aquatic weed Hydrilla verticillata (L.f.) Royle. Bioresour. Technol. 2010, 101, 2573-2579. [CrossRef] [PubMed]

27. Yang, M.; Jawitz, J.W.; Lee, M. Uranium and cesium accumulation in bean (Phaseolus vulgaris L. var. vulgaris) and its potential for uranium rhizofiltration. J. Environ. Radioact. 2015, 140, 42-49. [CrossRef]

28. NIAST. Methods of Soil and Plant Analysis; National Institute of Agricultural Science and Technology: Suwon, Korea, 2000.

29. Zayed, A.; Gowthaman, S.; Terry, N. Phytoaccumulation of trace elements by wetland plants: I. Duckweed. J. Environ. Qual. 1998, 27, 715-721. [CrossRef]

30. Ghosh, M.; Singh, S. A comparative study of cadmium phytoextraction by accumulator and weed species. Environ. Pollut. 2005, 133, 365-371. [CrossRef]

31. Langmuir, D. Uranium solution-mineral equilibria at low temperatures with applications to sedimentary ore deposits. Geochim. Cosmochim. Acta 1978, 42, 547-569. [CrossRef]

32. Mkandawire, M.; Dudel, E.G.; Taubert, B. Accumulation of uranium in Lemna gibba L. in relation to milieu conditions of tailing waters in abandoned uranium mines in Germany. Mine Water Process Policy Prog. 2004, 2, 9-18.

33. Mkandawire, M.; Taubert, B.; Dudel, E.G. Capacity of Lemna gibba L. (Duckweed) for Uranium and Arsenic Phytoremediation in Mine Tailing Waters. Int. J. Phytoremediat. 2004, 6, 347-362. [CrossRef]

34. Pratas, J.; Paulo, C.; Favas, P.J.; Venkatachalam, P. Potential of aquatic plants for phytofiltration of uranium-contaminated waters in laboratory conditions. Ecol. Eng. 2014, 69, 170-176. [CrossRef]

35. Ramaswami, A.P.A.; Carr, P.; Burkhardt, M. Plant-Uptake of Uranium: Hydroponic and Soil System Studies. Int. J. Phytoremediat. 2001, 3, 189-201. [CrossRef]

36. Tomé, F.V.; Rodríguez, P.B.; Lozano, J. The ability of Helianthus annuus L. and Brassica juncea to uptake and translocate natural uranium and 226Ra under different milieu conditions. Chemosphere 2009, 74, 293-300. [CrossRef] [PubMed]

37. Mkandawire, M.; Taubert, B.; Dudel, E.G. Resource manipulation in uranium and arsenic attenuation by Lemna gibba L.(duckweed) in tailing water of a former uranium mine. Water Air Soil Pollut. 2005, 166, 83-101. [CrossRef]

38. Rodríguez, P.B.; Tomé, F.V.; Fernández, M.P.; Lozano, J. Linearity assumption in soil-to-plant transfer factors of natural uranium and radium in Helianthus annuus L. Sci. Total Environ. 2006, 361, 1-7. [CrossRef] [PubMed]

39. Gupta, D.K.; Vuković, A.; Semenishchev, V.S.; Inouhe, M.; Walther, C. Uranium accumulation and its phytotoxicity symptoms in Pisum sativum L. Environ. Sci. Pollut. Res. 2020, 27, 3513-3522. [CrossRef] [PubMed]

40. Sasmaz, A.; Obek, E. The accumulation of arsenic, uranium, and boron in Lemna gibba L. exposed to secondary effluents. Ecol. Eng. 2009, 35, 1564-1567. [CrossRef]

41. Overall, R.A.; Parry, D.L. The uptake of uranium by Eleocharis dulcis (Chinese water chestnut) in the Ranger Uranium Mine constructed wetland filter. Environ. Pollut. 2004, 132, 307-320. [CrossRef]

42. Yang, M.; Her, N. Perchlorate in Soybean Sprouts (Glycine max L. Merr.), Water Dropwort (Oenanthe stolonifera DC.), and Lotus (Nelumbo nucifera Gaertn.) Root in South Korea. J. Agric. Food Chem. 2011, 59, 7490-7495. [CrossRef] 